received no mention in the principal New York financial pages. ${ }^{x 4^{8}}$ Judging their interest in the case on the basis of what they had printed previously, it may be that the papers would have printed a notice of the removal if the commission release had concisely summarized the background of the case insofar as it pertained to the lifting of the stop order. Such a situation merely supports the suggestion that the commission consider carefully the "weighting" of their releases, and the effect they have on newspaper publicity.

\title{
EFFECT OF THE NATIONAT BANKRUPTCY ACT ON STATE POWER OVER CORPORATE REORGANIZATION
}

Since Congress has provided for corporate reorganization under the bankruptcy power, ${ }^{,}$a question is raised as to the effect of this action upon state power over corporate reorganization. The question may become especially important if reorganizers seek state court reorganizations in order to avoid the reform provisions of Chapter $X$ of the National Bankruptcy Act. ${ }^{2}$ This path is open to reorganizers not only through the equity receivership but through recent amendments to state corporation acts. ${ }^{3}$ The grant of power under these statutes

${ }^{148}$ Note 95 supra, and accompanying text.

r Chapter X of the National Bankruptcy Act as amended in 52 Stat. 883 et seq. (I938), II U.S.C.A. $\S 5$ or et seq. ( 1939 ). The constitutionality of similar legislation has been upheld, Continental Illinois Nat'l Bank \& Trust Co. v. Chicago, R. I. \& P. R. Co., 294 U.S. 648 (I935) (sustaining $\$ 77$, which provided for railroad reorganizations); Campbell v. Alleghany Co., 75 F. (2d) 947 (C.C.A. $4^{\text {th }}$ I935) (sustaining $\$ 77 \mathrm{~B}$, the predecessor of Chapter X); In re Central Funding Co., 75 F. (2d) 256 (C.C.A. 2 d 1935) (sustaining $\$ 77$ B); cf. In re Tennessee Pub. Co., 8I F. (2d) 463 (C.C.A. 6th I936) (sustaining $\$ 77$ B).

${ }^{2}$ See discussion of reform provisions in Rostow and Cutler, Competing Systems of Corporate Reorganization: Chapters X and XI of the Bankruptcy Act, 48 Yale L. J. I334 (I939); Levi, Corporate Reorganization and a Ministry of Justice, 23 Minn. L. Rev. 3 (1938).

3 These provisions were taken from the arrangements section of the English Companies Act. See Rosenberg, Reorganization-Yesterday, Today, Tomorrow, 25 Va. L. Rev. 129, I40 (1938); Fraser, Reorganization of Companies in Canada, 27 Col. L. Rev. 932 (I927). These provisions make a plan of reorganization binding on dissenting creditors and stockholders when consented to by a majority in number representing three-quarters in amount of the creditors, or of each class thereof, and by the holders of (usually) three-quarters of the voting stock, or of each class thereof, and when approved by a court of competent jurisdiction. Some statutes stipulate that these provisions may be contained in the articles of incorporation, Colo. Stat. Ann. (Michie, I935) c. 4I, \&6; Del. Rev. Code (1935) § 2037; Kan. Gen. Stat. Ann. (Corrick, Supp. 1939) § I7-2803; La. Gen. Stat. Ann. (Dart, 1939) § II43; Mich. Comp. Laws (Mason, Supp. I935) § Ior 35-4; W.Va. Code Ann. (Michie \& Sublett, I937) \& 3or8. If they are not contained in the original articles but are added by amendment, clearly they bind only subsequent creditors, although under the reserved power to amend corporate charters, they may bind all stockholders unless the statute limits their operation to stockholders contracting subsequent to the amendment. See Del. Rev. Code (I935) § 2035; Mich. Comp. Laws (Mason, Supp. r935) \& ror35-4; W.Va. Code Ann. (Michie \& Sublett, 1937) § 3015. The Minnesota statute makes all corporations subject to these provisions unless the articles of incorporation specify otherwise, Minn. Stat. (Mason, Supp. $x_{940}$ ) $87492-54$. Other statutes do not leave 
to a stated proportion of security holders to bind dissenters, and the absence of reform provisions, may make the state proceedings especially attractive. The purpose of this note is to examine the nature of state and federal power in bankruptcy and to determine whether state power over reorganization is suspended.

It has long been settled that the power of Congress to establish uniform laws on the subject of bankruptcies does not prohibit state bankruptcy legislation until the federal power is exercised. 4 The federal power, when exercised by the passage of a national bankruptcy system, operates on the state power in two ways. First, it deprives the states of jurisdiction by suspending all state laws which are regarded as bankruptcy laws. ${ }^{5}$ Second, state laws on the subject of debtor-creditor relations which are not regarded as bankruptcy laws are not suspended, and proceedings in the state courts under such laws, statutory or common law, for the distribution of a debtor's assets are valid unless superseded by an action in the federal bankruptcy court. ${ }^{6}$ Thus in a traditional bankruptcy action, the jurisdiction of the federal court must be asserted within four months after a state court has taken jurisdiction of the debtor's assets under a creditor's bill in order to supersede the state court action; if this requirement is met, the federal court assumes control over the debtor's assets and distributes them in accordance with the federal law.7 But where the state law is suspended rather than superseded, state courts are without jurisdiction over the debtor's assets. ${ }^{8}$ As a result of suspension, federal jurisdiction in bankruptcy may be invoked more than four months after a state insolvency

the applicability of the provisions to be determined by the articles of incorporation, but include the provisions in the dissolution and liquidation sections, making reorganization an alternative to winding-up, Ill. Rev. Stat. (1939) c. 32, $\S$ 157.90; Pa. Stat. Ann. (Purdon, I938) tit. I5, § 2852-II09; Wash. Rev. Stat. Ann. (Remington, Supp. 1939) $\S 3803-58$. It has been said that these provisions were drafted because of doubt that the court had power to bind non-assenting creditors or shareholders to a reorganization plan without statutory sanction. See Commissioners' Note to $\$ 59$ of the Uniform Business Corporation Act, 9 U.L.A. I02-3 (1932), which criticizes the contract theory underlying those statutes which allow the corporation to decide, in the articles of incorporation, whether to be governed by these reorganization provisions.

4 Sturges v. Crowninshield, 4 Wheat. (U.S.) 122, 196 (1819).

5 Int'l Shoe Co. v. Pinkus, 278 U.S. 26r (r929). The Court spoke of the Arkansas statute as "superseded" by the Bankruptcy Act; the preferable term, according to the usage in this note, is "suspended."

${ }^{6}$ Boese v. King, I08 U.S. 379 (1883); Pobreslo v. Boyd Co., 287 U.S. 5 I8 (I933).

7 Glenn, Liquidation $\$ \S 228,579$ (I935). But the four-month limitation may not apply to a state court action instituted by a stockholder, unless creditors have filed claims with the state receiver in the stockholder's action more than four months before bankruptcy. See 4 Univ. Chi. L. Rev. 134, I35 (1936). The four-month limit does not apply to supersession by a federal court in reorganization. See note 39 and related text infra.

${ }^{8}$ In re Weedman Stave Co., 199 Fed. 948 (D.C. Ark. I9r2); In re Curtis, 91 Fed. 737 (D.C. Ill. 1899$)$. 
proceeding is begun.9 Furthermore, a dissenting creditor need not invoke the federal bankruptcy jurisdiction, but may attack the state court proceedings collaterally by attaching the property in the control of the state court, ${ }^{10}$ and thereby gain a preference which will be valid unless a petition in bankruptcy is filed within four months. Even if the state court proceedings are carried to a conclusion through failure to attack them, the discharge of the debtor does not bar an action to collect the debt. ${ }^{\text {Ir }}$ But if the insolvent estate is distributed among creditors by order of the state court, the distribution possibly will be sustained on the basis of the dissenter's laches, and distributees will thus be protected against attachment. ${ }^{\mathrm{r}}$

Inasmuch as a state act is suspended only if it is bankruptcy legislation, it has become necessary for courts to consider the nature of bankruptcy. Several tests have been suggested. According to the involuntary test, a law allowing a creditor to compel the application of the debtor's property to the payment of his debts despite the debtor's opposition, is a bankruptcy law. ${ }^{13}$ The coercion test emphasizes equal distribution of the debtor's property, the significant coercion being that exerted on the creditors to prevent a race of diligence and the granting of preferences by the debtor. ${ }^{I_{4}}$ Under this test the law compelling equal distribution may be voluntary or involuntary as to the debtor. The two tests represent the property distribution or creditor relief aspect of bankruptcy. A third test, representing the debtor relief aspect, stresses the fact that the law provides for the debtor's discharge from the balance of his debts after his nonexempt property has been distributed among his creditors. ${ }^{15}$

The courts have generally accepted the discharge test. The application of this test results in the suspension of only some of the devices for the distribution of a debtor's property under state law. A device at common law is the assignment for the benefit of creditors. An assignment, made through the voluntary action of the assignor-debtor regardless of the consent or opposition of creditors, prevents a creditor's race for the attachment of the property because title is

9 In re Weedman Stave Co., Ig9 Fed. 948 (D.C. Ark. I9I2).

so Int'l Shoe Co. v. Pinkus, 278 U.S. 26I (Ig29).

II First Nat'l Bank of Guilford v. Ware, 95 Me. 388, $5 \circ$ Atl. 24 (Igor).

12 Cf. Northern Pacific R. Co. v. Boyd, 228 U.S. 482, 508-Io (rgr 3 ); Boese v. King, Io8 U.S. 379,386 (I883); Mayer v. Hellman, 9 I U.S. 496 , 5 OI (I875), in which the Court, discussing preferences voidable by the institution of bankruptcy jurisdiction within the statutory period, said that preferences not thus avoided are "presumed" to be "acquiesced in by the creditors."

3 [1938] Wis. L. Rev. 302.

${ }^{24}$ Radin, What Is a Bankruptcy Act?, 20 A.B.A.J. 792 (r934), advocating the coercion test, criticizes the involuntary test on the ground that a levy of execution on a debtor's property by a single creditor is likewise involuntary.

75 The discharge test has been criticized on the ground that since discharge was not included in the original English bankruptcy legislation, it is not essential to a bankruptcy system, Glenn, Iiquidation 2ro (I935). It is suggested that a test of bankruptcy is whether or not the distribution of the debtor's assets can be made by act of the parties or whether court action is necessary, ibid., at 2rr; cf. In re Sievers, 9r Fed. 366, 368 (D.C. Mo. I899). 
placed in an assignee, and does not result in the discharge of unpaid obligations. ${ }^{16}$ The power to make assignments is not suspended by the passage of a federal bankruptcy law. ${ }^{17}$ Some jurisdictions also recognize the power of an assignor to include in the deed of assignment a release provision which binds debtors who share in the distribution under the assignment; creditors who refuse to accept a dividend in the distribution retain their claims against the debtor. Other courts refuse to recognize this power of an assignor on the ground that it allows the assignor to coerce creditors into granting releases by putting all his present property beyond their reach unless they consent to his discharge, or on the ground that such an assignment is a fraudulent conveyance unless it further provides that any surplus remaining after distribution among creditors consenting to the release shall be distributed among nonassenting creditors. ${ }^{18}$ Where the power of an assignor to exact releases is recognized, it is probably not suspended when the federal government occupies the bankruptcy field. Such releases are said to take effect by contract of the parties, while it is discharge by force of statute which characterizes bankruptcy under the discharge test. 9

State statutes which codify the common law assignment and add administrative safeguards, such as the bonding of the assignee and court supervision of his accounts, are not suspended by the passage of federal bankruptcy legislation..$^{20}$ But if a statute adds a discharge provision, the statute may be wholly suspended, or the discharge provision may be excised. ${ }^{2 x}$

${ }^{16}$ See in general Glenn, Liquidation c. $x$ (x935); Mulder and Solomon, Effect of the Chandler Act upon General Assignments and Compositions, 87 U. of Pa. L. Rev. 763, 765-6, 768-72 (I939).

17 Mayer v. Hellman, 9I U.S. 496 (1875) (note that the Court apparently regarded equally as important as the lack of a discharge provision the fact that an assignment is not adverse to creditors, and that the statute did not compel assignments); Stellwagon v. Clum, 245 U.S. 605, $6 \mathrm{I}_{7}$ ( $\mathrm{rg}$ I8) (here the lack of a discharge provision was stressed); Maltbie v. Hotchkiss, 38 Conn. 80 (I87I).

${ }^{88}$ Upholding the release provision: Patty-Joiner \& Eubank Co. v. Cummins, 93 Tex. 598, 57 S.W. 566 (1900); Haijek \& Simecek v. Luck, 96 Tex. 5I7, 74 S.W. 305 (r903). Holding the release provision invalid: Nelson v. Harper, I22 Ark. 39, I82 S.W. $5^{19}$ (1916). See Glenn, Liquidation § IIg (I935).

${ }^{29}$ Haijek \& Simecek v. Luck, 96 Tex. 517, 74 S.W. 305 (rgo3); cf. Int'l Shoe Co. v. Pinkus, 278 U.S. 26r, 268 (1929); Johnson v. Star, 287 U.S. 527 (r933); In re McElwain, 296 Fed. Ir 2 (C.C.A. 3 d I924) (the discharge feature of the Pennsylvania statute, Pa. Stat. Ann. (Purdon, I930) tit. 39, $\$ 100$, was later said to be suspended, under the authority of the Pinkus and Star cases, in Fidelity Trust Co. v. Union Nat'l Bank of Pittsburgh, 3I3 Pa. 467, 485-6, I69 Atl. 209, 216-I7 (I933)).

${ }^{20}$ Mayer v. Hellman, 9r U.S. 496 (I875); Finch v. Watson Investment Co., I84 Ark. 3 I2, 42 S.W. (2d) $2 \mathrm{I}_{4}$ (193r); Beck v. Parker, 65 Pa. 262 (1870).

2x Statute suspended: Int'I Shoe Co. v. Pinkus, 278 U.S. 26I (I929) (the court refused to consider the statute merely an assignment statute because it provided for the transfer of the property under "conditions intended to secure the debtor's discharge"); Tacoma Grocery Co. v. Doersch, 168 Wash. 606, I2 P. (2d) 929 (1932) (note synonymous use of "suspend" and "supersede"; also note that although not mentioned by the court, the statute in question con- 
Several state and lower federal courts have gone further and invalidated state statutes not containing discharge provisions. These courts have emphasized the so-called coercion test, suspending state statutes which compel equal distribution of the debtor's assets. ${ }^{22}$ As additional reasons for suspending the Illinois assignment statute, it was said in $\mathrm{In}$ re Curtis ${ }^{23}$ that Congress, by making the assignment for the benefit of creditors an act of bankruptcy, intended that the debtor's estate be administered in the manner prescribed by the National Bankruptcy Act; and in Harbaugh v. Costello ${ }^{24}$ that the constitutional re-

tained a discharge provision, Wash. Rev. Stat. Ann. (Remington, I932) $\S$ rroo); Hasbrouck v. La Febre, 23 Wyo. 367, I52 Pac. I68 (Igr5); Pelton v. Sheridan, 74 Ore. I76, I44 Pac. 4Io (Igr4); Ketcham v. McNamara, 72 Conn. 709, 46 Atl. 146 (rgoo). Discharge provision excised: Pobreslo v. Boyd Co., 287 U.S. 5 I8 (I933); Johnson v. Star, 287 U.S. 527 (r933); Boese v. King, 108 U.S. 379 ( 1883 ).

If a state statute is wholly suspended, it is said to be a state insolvency law; if only the discharge provision is suspended, it is said that the statute is merely a codification of the common law assignment with a discharge provision. Occasionally, however, a state "insolvent" law is not suspended because it is really only an assignment statute. See, e.g., Maltbie v. Hotchkiss, 38 Conn. $80(1871)$. It has been suggested that whether a statute will be regarded as an insolvency or assignment statute depends on whether "the direct aid of the courts" is necessary, as in the Pinkus case, or whether, despite statutory regulation, distribution of the debtor's assets is made under "a trust created by the debtor's own conveyance," as in the Pobreslo case, Glenn, Liquidation 2rI-I2 (r935).

In addition to a release under a common law assignment, Haijek \& Simecek v. Luck, 96 Tex. $5^{17}, 74$ S.W. 305 ( 1903$)$, a release can also be effected on ordinary contract principles, Brown Shoe Co. v. Beall, Io7 S.W. (2d) $45^{6}$ (Tex. Civ. App. 1937).

$\approx$ In re Salmon \& Salmon, 143 Fed. 395 (D.C. Mo. I906); In re Smith, 92 Fed. I35 (D.C. Ind. 1899 ) (the court erroneously assumed that if the state statute was not suspended, the state court, getting jurisdiction before the federal bankruptcy jurisdiction was invoked, could not be ousted by the federal court within the four-month period; it overlooked the fact that even if the state statute is in force, the jurisdiction of the federal court is not concurrent with that of the state court, but paramount to it); In re Reynolds, Fed. Cas. No. II723 (C.C. R.I. 1874). The authority of the first two cases may be doubted because the decision in each could have rested on the point of supersession instead of suspension.

${ }^{23} \mathrm{gr}$ Fed. 737, 74I (D.C. Ill. I8g9) (if the Illinois court had not held the Illinois assignment statute an insolvency law, the decision in this case could have rested on the supersession point).

${ }^{24}$ I84 Ill. Iro, Ir8, 56 N.E. $3^{63}, 3^{65}$ (I900) (note synonymous use of "suspend" and "supersede"). The Illinois statute had previously been declared an insolvency law, not merely a statute regulating assignments, because it turned partial assignments (assignments for the benefit of some creditors) into assignments for the benefit of all creditors, Hanchett v. Waterbury, II 5 Ill. 220, 32 N.E. I94 (I885) (concerned with the exclusive jurisdiction of the county court under the assignment statute). See Glenn, Liquidation \& II5 (I935). For the suggested effect of the decision in Harbaugh v. Costello on the liquidation, dissolution, and reorganization provisions of the Mllinois Business Corporation Act, see Miller, The Illinois Business Corporation Act and Bankruptcy Legislation, 29 Ill. L. Rev. 695 (1935). Although statutory assignments are suspended in Mllinois, the common law assignment remains, Pogue v. Rowe, ${ }_{23} 6$ IIl. I57, 86 N.E. 207 (Ig08). But if the uniformity argument made in the Harbaugh case to sustain suspension of statutory assignments is valid, common law assignments should also be suspended. 
quirement of uniform bankruptcy legislation would be disregarded if distribution of the debtor's assets were made under state law.

However valid the discharge test may be in the case of insolvent individuals, it is not significant in the case of insolvent corporations which are dissolved. The conflict with federal bankruptcy jurisdiction usually arises in these cases under state statutes providing for corporate dissolution. An insolvent corporation which is dissolved is in certain respects like an insolvent decedent; ${ }^{25}$ because the legal entity ceases to exist, there is no need for a discharge..$^{26}$ Furthermore, since only the state which created the corporation can dissolve it, and since on dissolution some provision must be made for distributing the corporation's assets, the enactment of federal bankruptcy legislation does not suspend state power over corporate dissolutions. ${ }^{27}$

If, however, a corporation may be put into bankruptcy, it cannot evade the operation of the bankruptcy law by resort to liquidation through dissolution proceedings in the state court. In other words, although state power to dissolve corporations is not suspended, ${ }^{28}$ it is liable to be superseded by a seasonably filed petition in bankruptcy. ${ }^{29}$ Even if the insolvent corporation has already been dissolved under state law, so long as undistributed assets remain, the federal court may assert bankruptcy jurisdiction in a suit subsequently in-

as State jurisdiction over the estates of insolvent decedents is not suspended by federal bankruptcy legislation, Gilbert's Collier, Bankruptcy 3 (4th ed. 1937).

${ }^{6}$ See Exploration Mercantile Co. v. Pacific Hardware \& Steel Co., ${ }_{77}$ Fed. 825 (C.C.A. 9th rgro); In re Hall, I2I Fed. 992 (D.C. Conn. I903); In re Merchants' Ins. Co., Fed. Cas. No. 944 I (D.C. Ill. I87I). In In re Weedman Stave Co., r99 Fed. 948 (D.C. Ark. I9I2), a statute providing for the liquidation of an insolvent corporation was held to be an insolvency law, the reason given being that discharge is not a necessary element of such a law. The provision that creditors' claims must be presented within a limited period or be barred was evidently not regarded as a discharge provision. But in Moody v. Port Clyde Development Co., I02 Me. 365,66 Atl. 967 (rgo7), such a provision was so regarded, and hence the statute was held suspended. Upon the repeal of that provision, the statute was held valid in Carter, Carter \& Meigs Co. v. Stewart Drug Co., II5 Me. 289, 98 Atl. 809 (IgI6).

27 Baker v. Monarch Mercantile Co., 269 Fed. 794 (C.C.A. 5th I92I) (dissolution petition by solvent corporation cannot be alleged as act of bankruptcy; note that if the corporation had made an assignment for the benefit of creditors, it would have been an act of bankruptcy regardless of solvency, West Co. v. Lea, r74 U.S. 590 ( 1899 ). The result of the West case is codified in section 3 of the Bankruptcy Act, 52 Stat. 844 (1938), II U.S.C.A. § 2 I (Supp. 1939)); see In re Standard Cordage Co., I84 Fed. 156 (D.C. N.Y. I9Io); Glenn, Liquidation $\$ 247$ (I935).

${ }_{28}$ But cf. Vassar Foundry Co. v. Whiting Co., 2 F. (2d) 240, 24I (C.C.A. 6th I924): "So far as the statute applies to solvent corporations, it clearly is not subject to be defined as an insolvency law. .... So far as it affects insolvent corporations, it has many of the aspects of an insolvency law, and perhaps enough of them to condemn it. As to that, we express no opinion." See also In re Weedman Stave Co., r99 Fed. 948 (D.C. Ark. rgra).

29 Platt v. Archer, Fed. Cas. No. II213 (C.C. N.Y. I872); see In re Watts and Sachs, I9o U.S. I, 27, 3I-2 (IgO3) (a contempt case); In re Standard Cordage Co., I84 Fed. I56 (D.C. N.Y. Igro). 
stituted. ${ }^{\circ \circ}$ Although such a bankruptcy action can be sustained as a suit to settle the affairs of a corporation under a state statute providing that a dissolved corporation shall remain alive in order to settle and close its affairs, ${ }^{35}$ such a statute is probably not an essential basis for bankruptcy jurisdiction invoked by creditors. ${ }^{32}$

Where a debtor corporation is not liquidated but undergoes a reorganization, the question of discharge becomes important. If the corporation is not insolvent in the bankruptcy sense, it can be said that no discharge is involved in the reorganization. For if the corporation is insolvent only in the sense that it cannot pay its debts as they mature, theoretically there are sufficient assets to pay all obligations on liquidation. Since, however, the object of reorganization is to prevent liquidation and to preserve going-concern value, distribution is made to creditors in the form of securities in the reorganized corporation. This readjustment of the debt and capital structure of the corporation involves only extension of corporate obligations, rather than composition and discharge. But if the corporation is insolvent in the bankruptcy sense, the application of the "fixed principle" 33 of absolute priority, ${ }^{34}$ which results in the elimination of some inferior classes of creditors from the reorganized corporation, will, in some sense, result in discharge. Consequently, the enactment of federal bankruptcy legislation on the subject of corporate reorganizations should result in the suspension of state jurisdiction in cases where there is insolvency in the bankruptcy sense.

There are several reasons why suspension will probably not result in reorganization cases. Reorganization may be achieved either through an equity receivership or under statute. The conceptual picture surrounding the equity receivership does not include discharge of the debtor corporation's obligations. The device normally used to achieve reorganizations through the equity receivership is a foreclosure or execution sale of the debtor corporation's property to a new corporation which, by virtue of the sale, takes the property

${ }^{30}$ In re Double Star Brick Co., 2ro Fed. 980 (D.C. Cal. rgr3); In re Storck Lumber Co., I I4 Fed. 360 (D.C. Md. Ig02).

${ }^{35}$ In re Munger Vehicle Tire Co., I59 Fed. gor (C.C.A. 2d Igo8).

${ }^{32}$ Hammond v. Lyon Realty Co., 59 F. (2d) 592 (C.C.A. 4th 1932); In re 2 I I East Delaware Place Bldg. Co., 76 F. (2d) 834 (C.C.A. 7 th I935); In re Park Beach Hotel Bldg. Co., 96 F. (2d) 886 (C.C.A. 7 th I938). Such a statute, however, is essential to an action instituted by the corporation, Chicago Title \& Trust Co. v. Forty-One Thirty-Six Wilcox Bldg. Co., $3 \circ 2$ U.S. I 20 (I937) (a dissolved corporation cannot petition for reorganization under section $77 \mathrm{~B}$ after the expiration of the statutory period within which it remains alive); cf. In re Int'l Sugar Feed Co., 23 F. Supp. 197 (Minn. I938) (a dissolved corporation, which remains alive for the statutory period for the purpose of closing its affairs, can petition for reorganization under section $77 \mathrm{~B}$, in the absence of express statutory prohibition).

${ }_{33}$ Northern Pacific R. Co. v. Boyd, 228 U.S. 482 (Igr3).

34 Case v. Los Angeles Lumber Products Co., 308 U.S. Io6 (1939), noted in 7 Univ. Chi. L. Rev. 549 (I940); see Dodd, The Los Angeles Lumber Products Company Case and Its Implications, 53 Harv. L. Rev. 7 I3 $_{3}$ (1940); Strict Priority in Bankruptcy Reorganization, 49 Yale L. J. I099 (I940). 
free from all claims except those arising from the reorganization plan, unless the sale can be attacked as a fraudulent conveyance. ${ }^{35}$ There is no discharge in the bankruptcy sense because creditors have a (worthless) right of action for the balance, if any, of their claims against the old corporation..$^{36}$

State statutory reorganizations, on the other hand, apparently do not require a sale of the property to a new corporation. Indeed, one of the advantages of a statutory system over the equity receivership is the elimination of the purely formal step of a sale. ${ }^{37}$ But if the reorganized corporation is the same corporate entity, it is no longer possible to employ the fiction that the corporation which owns the property after the reorganization is not the corporation which was indebted. Consequently, the reorganized corporation must be discharged from all claims not provided for in the reorganization $\operatorname{plan}^{38}$ if the purpose of the reorganization is to be effected. Since discharge is the test of whether state legislation is suspended, it would seem to follow that state reorganization statutes may be suspended by the federal act.

But several considerations indicate that state reorganization statutes may not be suspended by the federal act. It has been shown that because of the special interest which a state has in the corporations it has created, state dissolution statutes are not suspended. If a state can dissolve a corporation and incidentally distribute its assets, a state should also have the power to allocate interests in a reorganized corporation, unless the paramount jurisdiction of a federal court supersedes the action in the state court. Since there is no time limit to supersession by the federal court of a corporate reorganization in the state court, ${ }^{39}$ unlike the four-month limit in bankruptcy, suspension of state jurisdiction is unnecessary.

35 Northern Pacific R. Co. v. Boyd, 228 U.S. 482 (I9I3); I5 Fletcher, Cyc. Corp. $\$ 7327$ et seq. (1938); I Glenn, Fraudulent Conveyances and Preferences $\$ \$ 224,225$ (I940). It has been suggested that the principle of absolute priority is protected by the due process clause, Dodd, Reorganization through Bankruptcy: A Remedy for What?, 48 Harv. L. Rev. Iroo, II32 (I935).

${ }^{36}$ I5 Fletcher, Cyc. Corp. $\$ 7348$ (I938).

${ }^{37}$ Swaine, Corporate Reorganization under the Federal Bankruptcy Power, I9 Va. L. Rev. 3 I 7 (I933).

${ }^{38}$ Provision is made in sections 226 and 228 of the Bankruptcy Act for discharge of the debtor if the property is not conveyed to a new corporation, $5^{2}$ Stat. 898-9 (I938), II U.S.C.A. $\$ \$ 626,628$ (r939).

${ }^{39}$ In re Greyling Realty Co., 74 F. (2d) 734 (C.C.A. 2d I935); 52 Stat. 844, \& 2 (2I) (1938), II U.S.C.A. \& II (2I) (Supp. I939); 52 Stat. 902, § 257 (I938), II U.S.C.A. § 657 (I939). Under section $77 \mathrm{~B}$ it was held that if a mortgagee or trustee under a deed of trust was, under state law, in possession after condition broken, as owner, he could not be ousted by the bankruptcy court, In re Frances E. Willard Nat'l Temperance Hospital, 82 F. (2d) 804

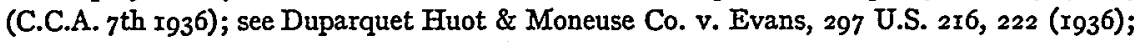
Tuttle v. Harris, 297 U.S. 225, 226 ( 1936 ). Section 257 was drafted to change this result.

A practical limitation on supersession exists because it is within the discretion of the federal court to allow a state reorganization to proceed, In re Prairie Ave. Bldg. Co., II F. Supp. 125 (Ill. 1935). 
Furthermore, discharge under a composition statute which gives a stated proportion of each class power to bind dissenters may be discharge by contract, rather than discharge by operation of law. It was early held, to prevent the invalidation of all state insolvency legislation by the impairment of contracts clause of the Federal Constitution, that creditors contract with debtors on the basis of existing insolvency legislation..$^{\circ}$ This type of contracting, however, was never considered sufficient to make discharge under a state insolvency statute a discharge by contract instead of by operation of law, and therefore was not sufficient to prevent suspension of state insolvency statutes when federal bankruptcy legislation was enacted.4x But there is a further type of consent involved in composition statutes which distinguishes them from ordinary insolvency statutes. The reorganization plan, unlike ordinary discharge, must be consented to by a stated proportion of each class sharing in the reorganized corporation. $4^{2}$ Each creditor in effect contracts to be bound by the assent of a certain proportion of his class, provided the assenters act with full knowledge of the circumstances and in the interest of the class. Where the insolvency of the corporation necessitates some inferior classes being excluded from the reorganization plan, these classes may be considered as having contracted for a fair valuation by the court which may result in their exclusion. If this view is accepted, courts should discriminate between types of state statutes. Those which approach the standards of the federal act in surrounding the reorganization process with safeguards may not be suspended, because the consent of the majority under such circumstances, being based on the opportunity to learn all the facts, amounts to a discharge by contract. But acts without safeguards looking toward complete knowledge may be suspended. At present, state corporate reorganization legislation is not sufficiently varied to make the suggested distinction practical.

In addition to the foregoing considerations, it appears that Congress has shown an intention not to suspend state jurisdiction over corporate reorganization. Section 256 of the Bankruptcy Act ${ }^{43}$ provides that a petition may be filed under Chapter $\mathrm{X}$ "notwithstanding the pendency of a prior mortgage foreclosure, equity, or other proceeding in a court of the United States or of any State in which a receiver or trustee of all or any part of the property of a debtor has been appointed or for whose appointment an application has been made." Other sections of Chapter $\mathrm{X}$ refer to equity or alternative proceedings in other courts. ${ }^{44}$ It is probable, therefore, that Congress intended not only to allow

40 Ogden v. Saunders, 12 Wheat. (U.S.) 213 (I827).

47 Int'l Shoe Co. v. Pinkus, 278 U.S. 26r (r929).

$4^{2}$ See note 3 supra.

4352 Stat. 902 ( 1938 ), II U.S.C.A. $\& 656$ (1939).

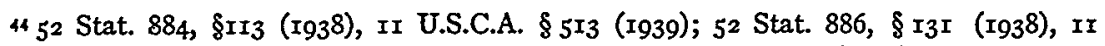
U.S.C.A. $\S 53$ I (I939); 52 Stat. $887, \S 146$ (I938), II U.S.C.A. $\S 546$ (I939); 52 Stat. 888 , $\S 148$ (I938), II U.S.C.A. $\$ 548$ (1939). 
state proceedings in the absence of supervening federal jurisdiction under Chapter X, but also to preserve the federal remedy of an equity receivership.

While it is undoubtedly within the power of Congress to preserve existing federal remedies, a serious question is raised as to the power of Congress to preserve state jurisdiction in bankruptcy after it has passed national bankruptcy legislation. The solution turns on interpreting the constitutional grant to Congress of power to establish uniform laws on the subject of bankruptcies.45 The uniformity requirement has been interpreted to mean geographical uniformity throughout the nation, and hence does not prevent Congressional recognition of state exemption laws in bankruptcy proceedings..$^{6}$ This interpretation would seemingly not prevent Congress from affirmatively indicating that state power over corporate reorganization shall not be suspended. Furthermore, it was indicated in International Shoe Co. v. Pinkus ${ }^{47}$ that the Supreme Court may regard the doctrine of suspension of state jurisdiction as resting on the implied intention of Congress, rather than on the constitutional requirement of uniformity. The Court declared:

The purpose to exclude state action for the discharge of insolvent debtors may be manifested without specific declaration to that end; that which is clearly implied is of equal force as that which is expressed. .... In respect of bankruptcies the intention of Congress is plain. The national purpose to establish uniformity necessarily excludes state regulation..... Congress did not intend to give insolvent debtors seeking discharge, or their creditors seeking to collect claims, choice between the relief provided by the Bankruptcy Act and that specified in state insolvency laws. $4^{8}$

If the implied intention of Congress is the basis for suspending state bankruptcy jurisdiction, the analogous doctrine of the negative implications of the commerce clause should be considered. In the field of so-called "national" interstate commerce, in which the courts say uniformity of regulation is required, the absence of federal legislation is said to indicate the intention of Congress to leave the field free from state regulation. When Congress by affirmative action opens the field to state regulation, the barrier is removed. ${ }^{49}$ So in bankruptcy, the clear intention of Congress not to exclude state jurisdiction over corporate reorganizations should be sufficient to overcome the contrary intention inferred by the courts from the mere exercise of the federal power. Should the exercise of state jurisdiction be undesirable in any case, the power of the federal court to supersede the state court proceedings provides sufficient protection for all parties to the reorganization. ${ }^{50}$

On the basis of the foregoing analysis, the decision in the recent case of First

45 U.S. Const. art. I, $\$ 8$.

${ }^{4} 6$ Hanover Nat'l Bank v. Moyses, I86 U.S. I8I (Ig02).

47278 U.S. 26I (I929).

$4^{8}$ Ibid., at 265.

${ }^{49}$ See Sholley, The Negative Implications of the Commerce Clause, 3 Univ. Chi. L. Rev. 556 (1936); Bikle, The Silence of Congress, 4r Harv. L. Rev. 200 (1927).

${ }^{30}$ See note 39 supra. 
Nat'l Bank in Albuquerque v. Robinson ${ }^{5 x}$ may be criticized. The circuit court of appeals held that the state statute providing for the liquidation or reorganization of insolvent corporations was suspended because the federal government had occupied the field under section $77 \mathrm{~B}$. If, despite the reasons advanced in this note in support of state jurisdiction in the reorganization field, state receivership statutes are held suspended under the reasoning of the Robinson case, states may nevertheless continue to exercise jurisdiction over reorganizations through the equity receivership. That this may be true is indicated by the attempt of counsel in the Robinson case to have the receivership treated as an equity proceeding, and by the reply of the court that the receiver was appointed under the state statute. This distinction, between an equity receivership and a state statutory receivership, receives further support from the statement in In re Sterba ${ }^{52}$ that the remedy of an equity receivership is not the equivalent of a proceeding under the reorganization acts. Hence it may be contended that federal legislation which suspends similar state statutes has no effect on the equity receivership, apart from the power of a federal court to supersede an equity proceeding. ${ }^{33} \mathrm{An}$ analogy in support of this result is found in the previous discussion of the assignment for the benefit of creditors: the assignment has been sustained, even though statutory assignments have been suspended, because it is a remedy which existed at common law. ${ }^{4}$ This approach, however, results in a return to the equity receivership, the evils of which reorganization legislation was intended to obviate. Nevertheless, the states should have the power to regulate the equity receivership for the purpose of eliminating its evils, as they have been held to have the power to provide legislative safeguards for the administration of assignments for the benefit of creditors. 55

\section{NEGRO RESTRICTIONS AND THE "CHANGED CONDITIONS" DOCTRINE}

During the last two decades many property owners in our larger cities have entered into covenants prohibiting the sale or rental of real estate to Negroes. Subdividers have included the restrictive covenant in deeds of conveyance, and "improvement associations" in already established residential neighborhoods have encouraged property owners in a given area to sign and record group agreements limiting the use or sale of their respective parcels to members of the

${ }^{5 x}$ ro7 F. (2d) 50 (C.C.A. roth 1939); see Effect of National Bankruptcy Act on State Insolvency Statutes, 49 Yale L. J. Iogo (r940). Contra: Gallagher v. Keystone Realty Holding Co., 333 Pa. 9, 3 A. (2d) 426 (I939) (upholding the appointment of a receiver for a corporation under a state statute whose discharge feature had been suspended (see note ig supra). The court followed the intention of Congress argument (see notes $43-4,47^{-9}$ supra, and related text)).

${ }^{52} 74$ F. (2d) 4 r3 (C.C.A. $7_{\text {th }}$ 9935). But cf. Finletter, Bankruptcy Reorganization 3 (r939). 53 See note 39 supra.

${ }^{54}$ See note 24 supra. 55 See note 20 supra. 